\title{
EFEKTIVITAS AROMATERAPI PEPPERMINT DAN PEMBERIAN SARI JAHE PADA MUAL MUNTAH IBU HAMIL DI PMB SITI JULAEHA PEKANBARU
}

\author{
${ }^{1)}$ Okta Vitriani, ${ }^{2)}$ Fatiyani Alyensi*, ${ }^{3)}$ Ari Susanti \\ Program Studi D III Kebidanan Jrusan kebidanan Poltekkes Kemenkes Riau \\ Jl. Melur No. 2013 Pekanbaru - Riau - Indonesia \\ E-mail : ${ }^{1)}$ okta@pkr.ac.id, ${ }^{2)}$ fatiyeni@pkr.ac.id, 3) ari@pkr.ac.id
}

\section{Kata Kunci:}

Peppermint; mual; muntah; jahe

\section{Keywords:}

Peppermint; nausea; vomitting; ginger)

\section{Info Artikel}

Tanggal dikirim: 26-8-2021

Tanggal direvisi: 7-10-2021

Tanggal diterima: 23-1-2022 DOI Artikel:

10.36341/jomis.v6i1.2042

Creative Commons AttributionNonCommercial-ShareAlike 4.0 International License.

\begin{abstract}
ABSTRAK
Ibu hamil yang mengalami mual muntah masih tinggi, yaitu hampir 80\% (Pasha, et al, 2012). Gejala yang dialami dari ringan sampai dengan berat hingga muntah hebat yang memerluan rawat inap dan apabila terjadi terus menerus dapat menyebabkan depresi bahkan sampai ingin mengakhiri kehamilannya. Tujuan dari penelitian ini untuk mengetahui efektivitas aromaterapi peppermint dan sari jahe terhadap mual muntah pada ibu. Penelitian ini adalah penelitian quasy eksperiment dengan rancangan penelitian two-groups pre test- post-test design. Penelitian dilaksanakan di PMB Siti Julaeha Pekanbaru pada bulan September sampai dengan November 2020 dengan sampel adalah ibu hamil trimester I sebanyak 30 sampel, yaitu 15 orang untuk perlakuan pepermin dan 15 orang untuk perlakuan jahe. Analiasa data dengan uji T. Hasil penelitian menunjukkan sari jahe dua kali lebih efektif mengurangi mual muntah dibandingkan dengan pemberian aromaterapi peppermint ( $p$ Value 0,001). Studi penemuan dengan takaran yang tepat dan beragam sebaiknya dilakukan untuk memastikan dosis efektif dan pengolahan jahe secara akurat. Hasil dari penelitian ini dapat dipakai sebagi bahan pertimbangan untuk memaksimalkan rancangan uji klinis untuk meningkatkan kemanjuran jahe dalam penanganan mual dan muntah.

\section{ABSTRACT}

Pregnant women who experience nausea and vomiting are still high, which is almost 80\% (Pasha, et al, 2012). Symptoms experienced from mild to severe to extreme vomiting that require hospitalization and if they occur continuously can cause depression and even want to end the pregnancy. The purpose of this study was to determine the effectiveness of peppermint aromatherapy and ginger extract on nausea and vomiting in mothers. This research is a quasi-experimental research with a twogroup pre-test-post-test design. The study was carried out at PMB Siti Julaeha Pekanbaru from September to November 2020 with 30 samples of first trimester pregnant women, 15 people for peppermint treatment and 15 people for ginger treatment. Data was analyzed by $T$ test. The results showed that ginger extract was twice as effective in reducing nausea and vomiting compared to peppermint aromatherapy ( $p$ Value 0.001). Inventory studies with precise and varied doses should be carried out to ensure effective dosing and accurate processing of ginger. The results of this study can be used as consideration for maximizing the design of clinical trials to increase the efficacy of ginger in treating nausea and vomiting.
\end{abstract}

\section{PENDAHULUAN}

Emesis gravidarum nausea and vomiting of pregnancy (NVP) adalah komplikasi umum yang sering terjadi pada masa kehamilan. . Kondisi ini mempengaruhi 50-90\% wanita hamil. Gejala yang dialami dari ringan sampai dengan berat hingga muntah hebat yang memerluan rawat inap.(Tan et al., 2018)

NVP adalah penyakit morbid secara fisik, mempengaruhi sebagian besar kehamilan. NVP memiliki dampak merugikan yang signifikan terhadap kualitas hidup (Tan et al., 2018). 
Mual dan muntah diperkirakan sering dialami oleh Wanita hamil trimester pertama di negara-negara Eropa, dengan angka kejadian $50 \%$ hingga $80 \%$. Kejadian Emesis gravidarum mulai terjadi sekitar minggu kelima stelah periode menstruasi terakhir, dan puncaknya pada usia kehamilan 8-12 minggu. Sekitar 5\% wanita akan mengalami gejala selama kehamilan. Meskipun morning sickness sering terjadi, hanya $17 \%$ wanita yang melaporkannya bahwa mereka mengalami hanya di pagi hari. Dalam sebuah studi prospektif, 160 wanita memberikan catatan harian di awal kehamilan, 74\% melaporkan mual dengan durasi rata-rata 34,6 hari, 'morning sickness' terjadi hanya $1,8 \%$, dan $80 \%$ melaporkan mual yang berlangsung sepanjang hari. Hanya setengah dari wanita yang melaporkan berkurang pada minggu ke14 , tetapi $90 \%$ baru berkurang pada minggu ke-22.(Lacroix et al., 2000)

Manifestasi paling parah dari NVP mengakibatkan hiperemesis gravidarum (HG). Meskipun tidak ada definisi standar HG, sebagian besar kriteria diagnostik meliputi: muntah terus-menerus sebelum 9 minggu setelah periode menstrusi terakhir, berat badan turun $>5 \%$ dari berat badan sebelum hamil, ketidakseimbangan elektrolit (hipokalemia), dan dehidrasi dan/atau ketonuria.(Jarvis \& Nelson-Piercy, 2011)

Kemampuan ibu untuk beradaptasi dengan perubahan dan masalah selama hamil, terutama emesis gravidarum sangat diperlukan. Dampak buruk bisa terjadi pada ibu dan janin yang ada di dalam rahim ibu, jika ibu tidak mampu beradaptasi dengan masalah emesis gravidarum. . Asupan nutrisi yang adekuat sangat diperlukan oleh ibu hamil yang mengalami mual muntah. Nutrisi yang seimbang sangat berguna untuk tubuh ibu dan untuk perkembangan untuk janin didalam kandungannya.

Bagi wanita yang mengalami NVP bisa mempengaruhi kualitas hidupnya. Lima puluh persen wanita mengatakan NVP mempengaruhi kemampuan mereka untuk bekerja, sebanyak 35\% membutuhkan waktu istirahat dari pekerjaan (rata-rata, 62 jam), $50 \%$ mengatakan NVP mempengaruhi hubungan mereka dengan keluarga dan pasangan, dan 55\% melaporkan mengalami depresi. Berdasarkan hasil survey kulaitas hidup, skor untuk wanita dengan NVP lebih buruk daripada skor wanita yang melaporkan depresi kronis. Lebih dari $80 \%$ wanita dengan Hiperemisis Gravidarum menyatakan bahwa NVP menyebabkan efek psikososial yang merugikan, termasuk kekhawatiran tentang ekonomi dan pekerjaan, depresi, kecemasan, dan ketakutan tentang kehamilan di masa depan dan bahkan berencana mengakhiri kehamilan. (King \& Murphy, 2009)

Mual dan muntah sering diabaikan oleh ibu hamil, karena ibu hamil menganggap, kejadian ini adalah hal yang lumrah yang biasa dialami oleh semua wanita hamil. Padahal, mual dan muntah dalam kehamilan mempunyai dampak yang berat, dan banyak ibu hamil tidak mengetahui hal ini. Akibat dari mual dan muntah ini, bisa mempengaruhi semua aspek kehidupan ibu hamil, seperti keluarga, pekerjaan, dan kehidupan sosialnya. Kecemasan salah satu dampak yang bisa diakibatkan oleh kejadian mual dan muntah ini, bahkan ada yang merasa terisolasi secara sosial dan memicu depresi. Kehidupan keluarga, sosialisasi dan aktivitas kehidupan sehari-haripun bisa terganggu karena Emesis gravidarum. Sehingga keadaan ini akan meningkatkan terjadinya stress pada ibu hamil (Lete \& Allué, 2016).

Kualitas hidup ibu hamil juga bisa dipengaruhi oleh mual dan muntah. Kualitas hidup ibu hamil bisa menurun karena mengalami emesis gravidarum ini. Kualitas hidup ibu hamil yang tidak memiliki gejala mual dan muntah lebih tinggi dibandingkan dengan kualitas hidup ibu hamil yang mengalami mual dan muntah. (Jarvis \& Nelson-Piercy, 2011)

Beratnya gejala mual muntah berbeda pada setiap ibu hamil, dan ini akan menentukan bagaimana penanganannya sesuai gejala yang dialami oleh ibu hamil. Ada beberapa penanganan yang bisa dilakukan untuk menanganai mual dan muntah penanganan mual dan muntah bisa dilakukan dengan mengkonsumsi obat 
sesuai beratnya gejala atau disebut dengan terapi farmakologi. Obat yang dianjurkan adalah pemberian antiemetik, antihistamin, antikolinergik, dan kortikosteroid. Terapi lain yang bisa digunakan untuk penanganan mual dan muntah tanpa obat, antara lain mengkonsumsi tanaman herbal yang dianjurkan seperti jahe. Terapi lain yang bisa dilakukan adalah dengan mengatur menu seimbang yang diperlukan bagi ibu hamil yang mengalami mual dan muntah. Terapi akupuntur juga sering diterapkan untuk mengurangi gejala emesis gravidarum ini. Dan yang bisa juga dilakukan oleh keluarga serta orang terdekat ibu hamil adalah dengan memberikan dukungan emosional (Ayu et al., 2017).

Morning sickness bisa diatasi dengan mengkonsumsi sari jahe. Banyak pakar yang merekomendasikan bahwa ibu hamil yang meminum 4 kali dalam sehari serbuk jahe yang direndam dengan air panas selama lima menit, bisa mengurangi mual dan muntah.

Aromaterapi juga menjadi pilihan pelengkap untuk mengurangi mual dan muntah. Efek ketenangan, kesegaran yang ditimbulkan dari aromaterapi bisa membantu ibu hamil untuk mengurangi gejala mual muntah yang sering terjadi pada awal kehamilan.

Jurnal obstetrik \& Ginekologi pernah membuat ulasan dan mempublikasikan jahe (ginger) tidak memiliki efek samping yang berbahaya bagi ibu hamil dan janin dalam kandungan. Jahe direkomendasikan sebagai salah satu alternatif yang bisa dipakai untuk mengurangi gejala morning sickness. (Joulaeerad et al. (2017).

Jahe (Zingiber officinale), adalah agen rempah-rempah dan penyedap di seluruh dunia, dianggap sebagai terapi alternatif yang efektif untuk pencegahan mual dan muntah. Menurut monografi HMPC Badan Obat Eropa, penggunaan obat jahe yang mengandung 1-2 g jahe per dosis didasarkan pada 'penggunaan yang mapan' untuk pengobatan mual dan muntah (Tóth et al., 2018).

Penggunaan jahe untuk pengobatan mual dan muntah sudah ada sejak zaman kuno. Dari senyawa bioaktif jahe, gingerol dan shogaol diakui sebagai komponen kunci untuk pencegahan muntah dengan berinteraksi dengan jalur sinyal reseptor 5hydroxytryptamine (Semwal et al., 2015). Selain itu, komponen ini dapat menyapu radikal bebas yang menyebabkan mual (Sheikhi et al., 2015).

Mual dan muntah pada ibu hamil juga bisa diatasi dengan herbal kahisat lainnya selain jahe, yaitu peppermint. Peppermint berasal dari negara-negara Mediterania. Seperti mint Jepang, peppermint memiliki persentase mentol yang besar. Peppermint adalah tumbuhan berkhasiat yang memilik kandungan menthol $(50 \%)$ dan methone (10-30\%) yang tinggi. Pemberian air rebusan jahe hangat juga efektif mengurangi frekuensi morning sickness dari 13 kali menurun menjadi 3,8 kali (Attokaran, 2011)

Praktik Mandiri Bidan (PMB) Siti Julaeha adalah salah satu Lahan Praktik yang telah memiliki perjanjian kerjasama dengan Jurusan Kebidanan sebagai bagi mahasiswa Jurusan Kebidanan. Dari wawancara mahasiswa dengan klien 10 orang ibu hamil, ditemukan keluhan ketidaknyamanan pada kehamilan sebanyak 7 orang yaitu mual dan muntah pada awal kehamilan.. Dari 7 orang ibu hamil yang mengalami mual dan muntah di dapatkan data bahwa $65 \%$ diantaranya mengatakan mual dan muntah yang dialami sampai mengganggu aktivitas sehari-hari.

\section{TINJAUAN PUSTAKA}

Kondisi mual muntah yang terjadi pada trimester awal kehamilan, biasanya akan berhenti. Karena keadaan ini bisa dikontrol dan gejalanya tidak terlalu berat. Akan tetapi bisa berdampak pada pemenuhan kebutuhan nutrisi, sehingga menyebabkan kekurangan cairan, berat badan menurun, kelemahan dan tidak seimbangnya elektroloit dalam tubuh. Efek samping yang bisa diakibatkan oleh kondisi mual muntah yang berlebihan atau hiperemisis gravidarum selain mengancam nyawa ibu juga berdampak pada janin yang dikandung. Kejadian abortus, bayi lahir 
rendah, kelahiran prematur, serta malforasi pada bayi baru lahir bisa meningkagt karena hiperemisis gravidarum. Mual muntah yang berlebihan pada wanita hamil juga meningkatkan terjadinya pertumbuhan janin terhambat (Intrauterine growth retardation/IUGR) (Ayu et al., 2017)

Mual dan untah yag dialami selama kehamilan dapat diatasi dengan berbagai cara, baik secara farmakologi maupun non farmakologi. Konsumsi sari jahe atau rebusan jahe, teknik relaksasi dan aromaterapi bisa disarankan oleh tenaga kesehatan sebagai tindakan non farmakologi untuk mengurangi gejala mual muntah.

Salah satu pengobatan botani paling populer selama kehamilan adalah jahe (Zingiber officinale Roscoe) Jahe adalah tanaman asli Asia. Rimpang aromatiknya digunakan sebagai bumbu, tetapi juga dalam pengobatan tradisional sejak zaman nenek moyang. Jahe milik pharmacopoeias resmi dari berbagai negara, termasuk Austria, Cina, Mesir, India, Inggris, Jepang, Swiss, dan Belanda. Selama sekitar 10 tahun, impor jahe di Eropa telah meningkat secara signifikan, dan banyak makanan serta suplemen makanan telah muncul di pasaran. Sebagian besar suplemen makanan ini didedikasikan untuk wanita hamil (Stanisiere et al., 2018)

Jahe (Zingiber officinale) adalah obat tradisional untuk mual dan muntah di banyak budaya dan telah diteliti untuk digunakan dalam mabuk perjalanan, mual di pagi hari, dan mual pasca operasi(Crichton et al., 2019)

Sejak zaman dahulu orang sudah mengenal jahe sebagai tanaman yang memiliki banyak manfaat yang berkhasiat. Orang-orang banyak memanfaatkan rimpang jahe sebagai ramuan obat herbal, dipakai sebagai bahan bumbu untuk memasak, bahkan jahe diolah menjadi minuman dan permen. Kandungan minyak atsiri di dalam jahe merupakan keunggulan tanaman jahe. Minyak atsiri ini menimbulkan efek yang menyegarkan dan bisa menghambat reflek muntah. Gingerol yang terkandung dalam jahe bisa bermanfaat untuk melancarkan darah dan membuat kerja saraf -saraf menjadi lebih baik. Khasiat minyak atsiri ini juga mencairkan ketegangan, stress, menekan rasa mual muntah dan meringankan serta menyegarkan kepala. Efek lain yang isa ditimbulkan oleh minyak atsiri jahe adalah aromanya yang harum. Sedangkan efek pedas, panas, rasa hangat di dalam tubuh diakibatkan oleoresis tanamam jahe. (Thomson et al., 2014)

Dari berbagai studi, jahe sangat dianjurkan sebagai bahan terapi yang efektif untuk menghilangkan dan mengurangi rasa mual dan muntah. Kejadian mual muntah yang sering dialami oleh ibu hamil di awal kehamilan bisa dikurangi dengan konsumsi jahe, baik pada primigravida maupun multigravida. (Stanisiere et al., 2018)

Salah satu bentuk pengobatan alternativ yang sering digunakan adalah aromaterapi Komponen utama dari aromaterapi adalah minyak atsiri yang bisa memberikan efek langsung pada tubuh. . Jiwa emosi seseorang bisa dipengaruhi oleh minyak atsiri yang terkandung dalam aromaterapi, minyak ini adalah cairan yang mudah menguap dan merupakan senyawa aromatic. Penyembuh yang kuat (powerful healing agent) disematkan juga pada minyak atsiri. Minyak ini sangat pekat (concentrated) dan memeilik khaisat yang sangat kuat dalam menyembuhkan (intensely energetic).

Konstituen utama daun peppermint adalah minyak esensial $(0,5-4 \%)$, yang mengandung monoterpen mentol $(30-55 \%)$ dan menthone $(14-32 \%)$. Daun peppermint secara tradisional digunakan secara internal, terutama dalam bentuk teh herbal, untuk menghilangkan gejala gangguan pencernaan seperti dispepsia, perut kembung dan mual. Minyak peppermint diambil secara internal, diencerkan dengan air, untuk menghilangkan gejala kejang gastrointestinal, perut kembung dan sakit perut (Hull \& Mentha, 2015)

Hasil studi pada 101 wanita hamil yang dilakukan pemberian aromaterapi inhalasi selama tiga hari dengan kombinasi minyak esensial lavender dan peppermint didapatkan 
hasil tingkat keparahan NVP berbeda secara signifikan dan sangat menurun pada aromaterapi hari ketiga jika dibandingkan dengan data awal pada kelompok intervensi (Sriningsih et al., 2017).

Efek aromaterapi peppermint dan plasebo sama dalam penurunan mual dan muntah selama hamil. Kesamaan ini bisa disebabkan oleh dampak psikologis intervensi pada wanita hamil. (Joulaeerad et al, 2018). Pada studi lain tentang minuman jahe, didapatan kesimpulan bahwa kejadian morning sickness pada ibu hamil dapat dikurangi dengan minuman jahe hangat. Terjadi penurunan kejadian mual muntah setelah diberikan minuman jahe hangat. Hasil uji statistik menunjukkan perbedaan yang sangat signifikan. $(p=0,000)$ (Ayu et al., 2017)

Pada penelitian yang lain juga menunjukkan hasil yang sama. Secara signifikan, kelompok sampel yang diberikan jahe, mengalami penurunan frekuensi mual dan sebanyak 52\%. Sedangkan kelompok yang diberikan placebo hanya mengalami penurunan frekuensi mual dan muntah sebanyak $17.7 \%(\mathrm{p}<0,05)$.

Studi yang lain juga menunjukkan bahwa frekuensi mual dan muntah dapat diturunkan 6 kali lebih besar dengan pemberian jahe instan dibanding plasebo $(\mathrm{p}<0,05)$. Hasil studi juga menunjukkan bahwa jumlah asupan energi 24 jam (kalori) ibu hamil yang mengalami mual dan muntah di awal kehamilan bisa ditingkatkan dengan pemberian jahe instan $(1629,58 \mathrm{kcal} \pm 468,04 \mathrm{kcal} ; \mathrm{p}<0,05)$ dibandingkan dengan pemberian placebo. Jumlah rerata asupan energi 24 jam meningkat (Setyawati et al., 2014)

Hasil penelitian yang lain menunjukkan hasil bahwa keluhan mual dan muntah pada ibu hamil lebih cepat diturunkan dengan konsumsi kombinasi piridoksin dan ekstrak jahe sebanyak $700 \mathrm{mg}$ per hari dibandingkan dengan hanya konsumsi piridoksin saja. Risiko terhadap ibu hami dan janin bisa dikurangi dengan memebrikan jahe dengan kadar yang lebih sedikit. (Pasha et al., 2012)

\section{METODE}

Penelitian ini adalah penelitian quasy eksperiment dengan rancangan penelitian twogroups pre test- post-test design. Hal yang ingin diketahui pada penelitian ini adalah bagaimana perbedaan penurunan frekuensi mual dan muntah pada ibu hamil trimester 1 , yang diberiakan sari jahe dan aromaterapi peppermint. Subjek yang memenuhi kriteria inklusi dilakukan observasi sebelum dilakukan perlakuan (pre test), kemudian di observasi lagi setelah mendapatkan perlakuan (post test). Tahap pelaksanaan penelitiana adalah ; Mengkaji karakteristik responden dan melakukan pre test degan menilai skor mual muntah yang dialami responden dengan menggunakan kuesioner yang harus diisi oleh responden; Melakukan intervensi terhadap responden, pada kelompok 1 dilakukan pemberian aromaterapi peppermint (sebanyak 3 tetes pada satu lembar tisu lalu di hirup dengan pernafasan dalam selama 15 menit dilakukan berturut turut selama 4 hari) dan kelompok 2 diberikan sari jahe $(500 \mathrm{mg}$ dicampur dengan $200 \mathrm{ml}$ air hangat) dilakukan selama 4 hari berturut - turut pada pagi hari setelah sarapan pagi; Melakukan penilaian post test yaitu dengan melihat skor mual muntah setelah di lakukan intervensi; Menilai efektivitas sebelum dan sesudah diberikan intervensi serta membandingakn efektivitas dilakukan aromaterapi peppermint dan pemberian sari jahe.

Data yang telah dikumpulkan, dilakukan analisis statistik dengan menggunakan tahapan analisis univariat dan bivariat . Uji paired sample test nilai signifikansi (2-tailed) digunakan pada analisis bivariate. Kesimpulan dari uji ini adalah terdapat adanya perbedaan yang signifikan antara variabel awal dengan variabel akhir $(<0,05)$, artinya ada pengaruh yang bermakna terhadap perbedaan penurunan frekuensi mual dan muntah pada sampel di masing-masing perlakuan. Dan jika tidak terjadi perbedaan yang signifikan sebelum dan sesudah perlakuan, bearti tidak terdapat pengaruh yang bermakna terhadap perlakuan pemeberian sari jahe dan aromaterapi peppermint $(\mathrm{p}>0,05)$ 


\section{HASIL DAN PEMBAHASAN}

Berikut adalah hasil uji statistik tentang efektifitas Sari jahe dan aromaterapi peppermint terhadap mual dan muntah pada ibu hamil.

\begin{tabular}{|c|c|c|c|c|c|c|c|}
\hline \multirow{2}{*}{$\begin{array}{c}\text { Kel } \\
\text { ompo } \\
\text { k }\end{array}$} & \multirow{2}{*}{$\mathbf{N}$} & \multicolumn{2}{|c|}{ PUQE Pre } & \multicolumn{2}{|c|}{ PUQE Post } & \multirow{2}{*}{$\begin{array}{l}\text { Mean } \\
\text { Rank }\end{array}$} & \multirow{2}{*}{$\begin{array}{l}P \\
\text { Val } \\
\text { ue }\end{array}$} \\
\hline & & Mean & SD & Mean & SD & & \\
\hline Jah & 15 & 9,47 & 2,38 & 5,06 & 4,06 & 4,41 & \\
\hline $\begin{array}{r}\text { Pap } \\
\text { ermin } \\
t\end{array}$ & 15 & 9,00 & 2,20 & 4,67 & 3,88 & 5,12 & 0.001 \\
\hline
\end{tabular}

Dari perhitungan uji statistik pada penelitian ini, di dapatkan hasil bahwa terdaoat perbedaan frekuensi mual dan muntah sebelum dan sesudah diberikan sari jahe dan peppermint. Rata-rata intensitas mual muntah pada kelompok intevensi sari jahe adalah 5,06 dengan nilai standar devisiasi pada 4,06. Pada kelompok intervensi inhalasi peppermint, di dapatkan hasil intensitas rata-rata derajat mual muntah 4,67 dengan stnadr deviasi 3,88. Dari analisis bivariat, didapatkan kesimpulan bahwa minuman sari jahe lebih efektif menurunkan derajat mual muntah dibandingkan dengan inhalasi aromaterapi peppermint dengan $p$ value $(0,001)$.

Jahe termasuk tanaman obat, yang merupakan tumbuhan rumpun berbatang semu. Jahe tidak hanya menjadi tambahan yang enak untuk masakan karena rasanya yang pedas dan unik, tapi juga bagus untuk kesehatan saat diolah menjadi minuman hangat yang menyegarkan. Sejak tahun 1500, jahe sudah dipakai dalam peoses terapi pengobatan di Negara India, Cina, dan Jepang. Asia Pasifik merupakan Negara asal jahe, yang tersebar dari India sampai Cina (Stanisiere et al., 2018)

Hasil studi menunjukkan bahwa frekuensi mual dan muntah lebih cepat diturunkan dengan pemberian sari jahe dibandingkan dengan inhalasi aromaterapi peppermint. Mual dan muntah yang disebabkan kehamilan umumnya terlihat dalam pengobatan keluarga, dan 50\% hingga 90\% kehamilan dipengaruhi oleh mual dengan atau tanpa muntah. Menurut penelitian terbaru, hingga $63 \%$ wanita mengalami mual dan muntah hingga 24 minggu kehamilan. Sementara hanya $0,3 \%$ sampai $2 \%$ ini kasus dianggap parah (disebut hiperemesis gravidarum, menyebabkan penurunan $5 \%$ dari berat badan sebelum hamil), semua bentuk kehamilan yang berhubungan dengan mual bisa mempengaruhi kualitas hidup. Dibandingkan dengan volume literatur tentang patogenesis dan pengobatan mual dan muntah akibat kehamilan secara umum, beberapa penelitian mengamati mual dan muntah muntah pada awal kehamilan (NVEP) (Thomson et al., 2014).

Mengenai khasiat dan keamanan, dari 15 penelitian dan 3 studi klinis prospektif telah dilakukan. NVP bisa dikurangi dengan pemberian jahe. Jahe adalah herbal yang efektif dan juga sangat aman karena tidak mengakibatkan risiko bagi ibu hamil dan janin yang dikandung. Frekuensi mual dan muntah pada ibu hamil bisa dikurangi dengan pemberian jage segar, yaitu dengan dosis 1 gram jahe segar per hari selama empat hari. (Stanisiere et al., 2018)

Semua orang bisa dan aman untuk mengkonsusmi jahe, karena sejak dahulu jahe sudah terbukti sebagai obat herbal yang sangat berkhasiat dan penuh manfaat. Jahe dapat diolah ke dalam berbagai bentuk. Selain jahe segar, jahe sudah diolah ke dalam berbagai bentuk. Ada banyak bentuk jahe yang bisa dikonsumsi, seperti jahe segar, jahe yang dikeringkan, dan bubuk jahe kering, acar. Jahe juga sudah banyak diawetkan, dikristalisasi, dan diberi rasa manis sehingga setiap orang bisa mengkonsumsi sesuai kebutuhan. Penyajian jahe juga ada dalam bentuk tablet, kapsul, tincture, ekstrak cair dan teh (Lete \& Allué, 2016)

Jahe mengandung minyak alami yang bernama gingerol yang berfungsi sebagai antiinflamasi dan antioksidan. Kandungan ini yang menyebabkan jahe memiliki rasa yang khas dan aroma yang kuat. Secara umum, jahe bisa mengobati flu dan masalah pencernaan seperti mual.

Jahe adalah pilihan pengobatan yang aman dan efektif untuk mual dan muntah dalam kehamilan dan sebanding dengan efektivitas vitamin B6. Penelitian yang mungkinkan dilakukan di masa yang akan datang perlu mengatasi potensi risiko dari dosis tinggi selama kehamilan, tetapi jahe merupakan 
herbal yang aman yang sudah digunakan selama berabad-abad untuk tujuan pengobatan serta sebagai bahan untuk membuat makanan (Bryer, 2005)

Peppermint dilaporkan memiliki efek menenangkan pada lambung, selain mengurangi mual, pada wanita dengan keluhan mual muntah pada kehamilan. Gabungan aromaterapi lemon dan peppermint dapat mengurangi intensitas mual dan muntah ringan hingga sedang selama kehamilan. Hasil penelitian Joulaeerad tahun 2017, menyatakan dengan pemberian aromaterapi peppermint, dapat menurunkan mual dan muntah $(\mathrm{P}<$ 0,001).

Hasil penelitian lain juga menunjukkan mual dan muntah pada ibu hamil trimester 1 , bisa dikurangai dengan pemeberian aroma terapi dan jahe dengan $p$ value $<0,05$ (Santi, 2013).

Hasil penelitian lain menunjukkan bahwa ada penurunan mual dan muntah dengan pemberian minyak atsiri peppermint (Pasha, et al, 2012)

Bagi ibu hamil dapat melakukan terapi komplemeter untuk pencegahan mual muntah pada kehamilan dengan pemberian aromaterapi peppermint sebanyak 3 tetes pada satu lembar tisu lalu di hirup dengan pernafasan dalam selama 15 menit dilakukan berturut turut selama 4 hari atau sari jahe, yaitu $500 \mathrm{mg}$ dicampur dengan $200 \mathrm{ml}$ air hangat selama 4 hari. Perlu diketahui oleh semua ibu hamil, mengkonsumsi jahe harus dengan dosis yang tepat, karena akan lebih aman untuk ibu hamil dan janin.

\section{KESIMPULAN}

Setelah perlakuan pada masing-masing kelompok sampel ibu hamil, didapatkan kesimpulan bahwa pemberian sari jahe jauh lebih efekrif menurunkan frekuensi mual dan muntah dibandingkan dengan pemberian aromaterapi peppermint. ( $p$ Value 0,001). Bagi ibu hamil yang mengalami mual dan muntah, dapat melakukan terapi komplemeter untuk pencegahan mual muntah pada kehamilan dengan pemberian aromaterapi peppermint dan konsumsi sari jahe.

\section{DAFTAR PUSTAKA}

Attokaran, M. (2011). 84 Peppermint. Natural Food Flavors and Colorants, 337-339.

Ayu, D. ., Andiani, D., Haniarti, \& Usman. (2017). Efektivitas Pemberian Jahe Hangat Dalam Mengurangi Frekuemsi Mual Muntah Pada Ibu Hamil Trimester 1. Fakultas Ilmu Kesehatan, Universitas Muhamadiyah Parepare. Isbn:978-9793812-41-0, 978-979.

Bryer, E. (2005). A literature review of the effectiveness of ginger in alleviating mild-to-moderate nausea and vomiting of pregnancy. Journal of Midwifery and Women's Health, 50(1), 2004-2006. https://doi.org/10.1016/j.jmwh.2004.08.0 23

Crichton, M., Marshall, S., Marx, W., McCarthy, A. L., \& Isenring, E. (2019). Efficacy of Ginger (Zingiber officinale) in Ameliorating Chemotherapy-Induced Nausea and Vomiting and ChemotherapyRelated Outcomes: A Systematic Review Update and Meta-Analysis. Journal of the Academy of Nutrition and Dietetics, 119(12), 2055-2068. https://doi.org/10.1016/j.jand.2019.06.00 9

Hull, S. M., \& Mentha, L. (2015). THR, PL.

Jarvis, S., \& Nelson-Piercy, C. (2011). Management of nausea and vomiting in pregnancy. Bmj, 342(7812), 1-8. https://doi.org/10.1136/bmj.d3606

Joulaeerad et al. (2017). Effect of Aromatherapy with Peppermint Oil on the Severity of Nausea and Vomiting in Pregnancy: A Single-blind, Randomized, Placebo-controlled trial. Giti Ozgoli, Midwifery and Reproductive Health Research Center, Shahid Beheshti University of Medical Sciences, Vali-Asr Avenue, Cross of Vali-Asr and Neiaiesh Highway, Opposite to Rajaee Heart Hospital, Tehran, Iran.

King, T. L., \& Murphy, P. A. (2009). 
Evidence-Based Approaches to Managing Nausea and Vomiting in Early Pregnancy. Journal of Midwifery and Women's Health, 54(6), 430-444. https://doi.org/10.1016/j.jmwh.2009.08.0 05

Lacroix, R., Eason, E., \& Melzack, R. (2000). Nausea and vomiting during pregnancy: A prospective study of its frequency, intensity, and patterns of change. American Journal of Obstetrics and Gynecology, 182(4), 931-937. https://doi.org/10.1016/S00029378(00)70349-8

Lete, I., \& Allué, J. (2016). The effectiveness of ginger in the prevention of nausea and vomiting during pregnancy and chemotherapy. Integrative Medicine Insights, 11, 11-17. https://doi.org/10.4137/IMI.S36273

Pasha, H., Behmanesh, F., Mohsenzadeh, F., Hajahmadi, M., \& Moghadamnia, A. A. (2012). Study of the effect of mint oil on nausea and vomiting during pregnancy. Iranian Red Crescent Medical Journal, 14(11), 744-747. https://doi.org/10.5812/ircmj.3477

Santi, D. S. (2013). Pengaruh Aromaterapi Blended Peppermint dan Ginger Oil terhadap Rasa Mual pada Ibu Hamil Trimester Satu di Puskesmas Rengel Kabupaten Tuban. Jurnal Sains Medika, $5(2)$, 52-55. https://www.kopertis7.go.id/uploadjurnal/ Dwi_Rukma_Santi_stikes_nu_tuban.pdf

Semwal, R. B., Semwal, D. K., Combrinck, S., \& Viljoen, A. M. (2015). Gingerols and shogaols: Important nutraceutical principles from ginger. Phytochemistry, 117, 554-568. https://doi.org/10.1016/j.phytochem.2015 .07 .012

Setyawati, N., Wahyuningsih, M. S. H., \& Nurdiati, D. S. (2014). Pemberian jahe instan terhadap kejadian mual muntah dan asupan energi pada ibu hamil trimester pertama. Jurnal Gizi Klinik Indonesia, 191. https://doi.org/10.22146/ijcn.18871

Sheikhi, M. A., Ebadi, A., Talaeizadeh, A., \&
Rahmani, H. (2015). Alternative Methods to Treat Nausea and Vomiting from Cancer Chemotherapy. Chemotherapy Research and Practice, 2015, 1-6. https://doi.org/10.1155/2015/818759

Sriningsih, I., Elisa, E., \& Lestari, K. P. (2017). Aromatherapy Ginger Use in Patients with Nausea \& Vomiting on Post Cervical Cancer Chemotherapy. Jurnal Kesehatan Masyarakat, 13(1), 59-68. https://doi.org/10.15294/kemas.v13i1.536 7

Stanisiere, J., Mousset, P. Y., \& Lafay, S. (2018). How safe is ginger rhizome for decreasing nausea and vomiting in women during early pregnancy? Foods, 7(4).

https://doi.org/10.3390/foods7040050

Tan, A., Lowe, S., \& Henry, A. (2018). Nausea and vomiting of pregnancy: Effects on quality of life and day-to-day function. Australian and New Zealand Journal of Obstetrics and Gynaecology, $58(3)$, 278-290. https://doi.org/10.1111/ajo.12714

Thomson, M., Corbin, R., \& Leung, L. (2014). Effects of ginger for nausea and vomiting in early pregnancy: A meta-analysis. Journal of the American Board of Family Medicine, 27(1), 115-122. https://doi.org/10.3122/jabfm.2014.01.13 0167

Tóth, B., Lantos, T., Hegyi, P., Viola, R., Vasas, A., Benkő, R., Gyöngyi, Z., Vincze, Á., Csécsei, P., Mikó, A., Hegyi, D., Szentesi, A., Matuz, M., \& Csupor, D. (2018). Ginger (Zingiber officinale): An alternative for the prevention of postoperative nausea and vomiting. A meta-analysis. In Phytomedicine (Vol. 50). Elsevier GmbH. https://doi.org/10.1016/j.phymed.2018.09 .007 